\title{
Comparative Proximate Composition of Maize (Zea mays L.) Varieties Grown in South-western Nigeria
}

\author{
Olufunso O. Adeniyi ${ }^{1,2 *}$, Oluwole S. Ariwoola ${ }^{1}$ \\ ${ }^{1}$ Federal College of Forestry, Forestry Research Institute of Nigeria, PMB 5054 Forest hill, \\ Ibadan, Oyo state, Nigeria \\ ${ }^{2}$ Biomedicinal Research Centre, Forestry Research Institute of Nigeria, PMB 5054 Forest hill, \\ Ibadan, Oyo state, Nigeria \\ * Corresponding author email: adeniyiolufunso@gmail.com
}

Received: 19 October 2018 / Revised: 09 December 2018 / Accepted: 13 January 2019 / Published: 27 January 2019

\begin{abstract}
Maize, a highly cultivated multipurpose cereal has different varieties grown globally. Six majorly known varieties (Hybrid red solo- $V_{1}$, Red solo- $V_{2}$, Solo- $V_{3}$, Popcorn- $V_{4}$, Small white- $V_{5}$ and Big white- $V_{6}$ ) found in south-western Nigeria were purposefully selected because of their abundance across the region and were analyzed for their proximate composition. Their composition of different nutrients varied; \% crude fat was significantly higher in $\mathrm{V}_{5}(4.25 \%), \mathrm{V}_{4}$ had a significantly higher $\%$ ash content of $1.93 \%, \%$ crude protein ranged from $9.32 \%-15.75 \%, \mathrm{~V}_{2}$ had a significantly low $\%$ crude fibre of $0.86 \%$, while $\mathrm{V}_{1}$ had a significantly higher $\%$ carbohydrate content of $74.40 \%$. Knowledge of the levels of nutrients present in the different varieties will help in choosing the variety that can suit any intended purpose. $V_{6}$ (Big white) seems to be the most preferable for human and animal consumption because of its significantly high content in protein and crude fibre coupled with a considerably high fat content.
\end{abstract}

Keywords: Cereal, Maize varieties, $\%$ Crude fat, $\%$ Ash, $\%$ Crude protein, $\%$ Crude fibre, $\%$ Carbohydrate, South-western Nigeria.

\section{Introduction}

Maize (Zea mays L.) is a widely consumed annual cereal crop cultivated globally. It is of the family Poaceae and considered to be a staple food in many parts of the world [1]. Its domestication and diversification by indigenous farmers rank as one of the greatest accomplishments of plant breeding. Archeological records suggest that maize was first brought into cultivation in Mexico and Central America [2]; it is a third leading crop of the world after rice and wheat, the world production of maize was 967 million metric tons and due to its highest yield potential among the cereals it is known globally as 'queen of cereals' [1]. In Nigeria, it is the most important cereal crop next to sorghum [3]. Maize has a variety of uses, it provides food and fuel for humans, feeds for animals; and can be used as raw materials in manufacturing industries [4]. Its grains have great nutritional values and can be processed into various types of products such as cornmeal, grits, starch, flour, tortillas, snacks, and breakfast cereals [2]. It can be eaten boiled, roasted, fried or popped [3]. Several studies have been conducted on the nutritional composition of maize, it has been found to contain a lot of beneficial nutrients ranging from carbohydrate, protein, macro elements, minerals, vitamins to phytochemicals [2], [5], [6]. Little work has been done on the comparison of the nutritional composition of different maize varieties in southwestern Nigeria; hence, this study aims to investigate the proximate composition of different varieties of maize grown in this region of Nigeria. Knowledge of the differences in proximate composition will help in selecting the best variety for human and animal consumption. 


\section{Materials and Methods}

\subsection{Sample Collection and Preparation}

Six different maize varieties used for this study were purchased from traders at Bodija market, Ibadan, Oyo State, Nigeria. Bodija market was purposefully selected because it is the biggest market known for the sale of food crops in the south-western region of Nigeria. The varieties are listed in Table 1.

Table 1: Maize varieties analyzed

\begin{tabular}{|l|l|}
\hline Varieties & Local Name \\
\hline$V_{1}$ & Hybrid red solo \\
\hline$V_{2}$ & Red solo \\
\hline$V_{3}$ & Solo \\
\hline$V_{4}$ & Popcorn \\
\hline$V_{5}$ & Small white \\
\hline$V_{6}$ & Big white \\
\hline
\end{tabular}

Extraneous substances were carefully separated from the air-dried samples, and they were milled into fine particles using Rico MG '601' Grinder Mixer. Representative samples of each of the varieties were taken and analyzed for their proximate composition using standard procedures described by Association of Official Analytical Chemists [7].

\subsection{Determination of Proximate Composition}

\subsubsection{Moisture Content}

$2.0 \mathrm{~g}$ of each sample was weighed (W1) and dried in an air oven at $105^{\circ} \mathrm{C}$ for 3 hours. It was cooled in a desiccator and reweighed. This was repeated until a constant weight was achieved (W2). The percentage moisture content was calculated as [7]:

$$
\% \text { moisture content }=\frac{W 1-W 2}{W 1} \times 100
$$

\subsubsection{Ash Content}

$2.0 \mathrm{~g}$ of each sample was weighed in a crucible and incinerated in a muffle furnace at $550^{\circ} \mathrm{C}$ for 8 hours until ash was obtained. The sample was then cooled in a desiccator and weighed. \% ash content was calculated as [7]:

$$
\% \text { ash }=\frac{W 3-W 1}{W 2-W 1} \quad x 100
$$

W3 = Weight of the crucible and the sample after ashing.

W2 $=$ Weight of the crucible and the sample before ashing.

W1 = Weight of the empty crucible

\subsubsection{Crude Fat}

$2.0 \mathrm{~g}$ of each sample was added to a pre-weighed filter paper which was dipped inside the Soxhlet extractor. It was fitted up with the reflux condenser and a flat bottom flask. The flask was filled to about $2 / 3$ with $n$-hexane. This was heated using water bath and allowed to reflux for 6 hours. After the extraction was completed, the wrapped filter paper containing the sample was dried in an air-oven at a temperature of $100^{\circ} \mathrm{C}$ for 1 hour and cooled in a desiccator. Weight of the sample was determined after extraction, \% crude fat was calculated as [7]:

$$
\% \text { Crude Fat }=\frac{W 1-W 2}{W 1} \times 100
$$

where $\mathrm{W} 1$ = weight of sample before extraction

$\mathrm{W} 2$ = weight of sample after extraction

\subsubsection{Crude Fibre}

$2.0 \mathrm{~g}$ of each of the defatted and dried sample was weighed and poured into a round bottom flask containing $200 \mathrm{~mL}$ of boiling $0.255 \mathrm{~N}$ sulphuric acid solution. The round bottom flask was connected to a condenser and brought to boil within a minute. Refluxing was done for 30 minutes with periodic swirling of the flask to remove particles adhering to the sides. This was filtered within 10 minutes using a preheated Buchner flask. The residue on the filter paper was washed with boiling water and the residue was transferred back into a clean round bottom flask containing $200 \mathrm{~mL}$ of boiling $0.313 \mathrm{~N}$ sodium hydroxide and refluxing was again carried out for 30 minutes. The hydrolyzed mixture (after letting it rest for 1 minute) was filtered within 10 minutes in a preheated Buchner flask. The residue was washed with boiling water, with $1 \% \mathrm{HCI}$ solution and then again with boiling water and finally with petroleum ether. The residue was then transferred into a pre-weighed crucible and oven dried at $105^{\circ} \mathrm{C}$ till constant weight, the weight was recorded. The crucible was immediately transferred into a muffle furnace operated at 
Adeniyi et al., Int. Ann. Sci.; Vol. 7, Issue 1, pp: 1-5, 2019

$550^{\circ} \mathrm{C}$ for $3 \mathrm{hrs}$, and then left to cool in a desiccator and weighed again. \% crude fibre was calculated as [7]:

$$
\% \text { Crude Fibre }=100(\mathrm{~A}-\mathrm{B}) / \mathrm{C}
$$

where:

$\mathrm{A}=$ weight of crucible with dry residue $(\mathrm{g})$

$\mathrm{B}=$ weight of crucible with ash $(\mathrm{g})$

$\mathrm{C}=$ weight of sample $(\mathrm{g})$

\subsubsection{Crude Protein}

$1.0 \mathrm{~g}$ of each sample was weighed and placed in Kjeldahl flask; $10.0 \mathrm{~g}$ potassium sulphate, $0.7 \mathrm{~g}$ mercuric oxide and $20 \mathrm{~mL}$ concentrated sulphuric acid were added. The flask was tilted at an angle in the digester, brought to boiling and retained until the solution was clear. Heating continued for 30 minutes more. Little paraffin wax was added to reduce the foaming. It was left to cool gradually adding $90 \mathrm{~mL}$ distilled water. After cooling, $25 \mathrm{~mL}$ of sodium sulphate solution was added and it was stirred. With the flask in a tilted position, glass bead and $80 \mathrm{~mL}$ of $40 \%$ sodium hydroxide solution were added; this led to the formation of 2 layers. The flask was quickly connected to a distillation unit and heated. $50 \mathrm{ml}$ of distillate containing ammonia in $50 \mathrm{~mL}$ of indicator solution was collected. At the end of the distillation, the receptor flask and the end of the condenser were removed. The distillate was titrated with standard $0.1 \mathrm{~N}$ hydrochloric acid solution. \% crude protein was calculated as [7]:

$\%$ Nitrogen in the sample $=$

$$
100\{[(\mathrm{~A} \times \mathrm{B}) /(\mathrm{C})] \times 0.014\}
$$

Crude protein $(\%)=$ nitrogen in sample $\times 6.25$ where: $\mathrm{A}=$ volume of hydrochloric acid used in titration $(\mathrm{mL})$

$\mathrm{B}=$ normality of standard acid

$\mathrm{C}=$ weight of sample $(\mathrm{g})$

\subsubsection{Total Carbohydrate:}

This was determined by subtracting the values of the aforementioned parameters from 100 (i.e. by difference method) [7].

$\%$ Carbohydrate $=100-(\%$ moisture $+\%$ ash + $\%$ crude fat $+\%$ crude fibre $+\%$ crude protein)

\section{$3 \quad$ Results}

The proximate composition of the different maize varieties is shown in Table 2. \% moisture content of the dried samples ranged from $11.10 \%$ $-12.45 \%$ with significant differences occurring between all the varieties except $\mathrm{V}_{2}$ (Red Solo) and $\mathrm{V}_{3}$ (Solo). $\mathrm{V}_{5}$ (small white) had a significantly higher value, while $\mathrm{V}_{6}$ (Big white) had a significantly lower value than all other varieties. $\%$ Fat content of all the samples was relatively low as a significantly higher value of $4.25 \%$ was present in $\mathrm{V}_{5}$ (small white); $\mathrm{V}_{1}$ (Hybrid red solo) on the other hand had a significantly lower value than all other varieties. \% Ash content ranged from $0.49 \% \quad-1.93 \% ; \quad V_{4}$ (popcorn) had a significantly higher value than all other varieties. $\%$ Crude protein was significantly higher in $\mathrm{V}_{6}$ (Big white), while $\mathrm{V}_{1}$ (Hybrid red solo) had the lowest value of $9.32 \%$; $\%$ Crude fibre ranged from $0.86 \%-1.74 \%$ with significantly higher value occurring in $\mathrm{V}_{6}$ (Big white); \% Carbohydrate ranged from $68.18 \%-74.40 \%$ with significant differences occurring between all the varieties.

Table 2: Proximate composition of each maize variety

\begin{tabular}{|l|l|l|l|l|l|l|}
\hline Sample & $\begin{array}{l}\text { \% Moisture } \\
\text { content }\end{array}$ & \% Fat & \% Ash & \% Protein & $\begin{array}{l}\text { \% Crude } \\
\text { Fibre }\end{array}$ & \% Carbohydrate \\
\hline V1 & $12.45 \pm 0.01 \mathrm{~d}$ & $1.29 \pm 0.01 \mathrm{a}$ & $1.00 \pm 0.00 \mathrm{~b}$ & $9.32 \pm 0.02 \mathrm{a}$ & $1.55 \pm 0.01 \mathrm{e}$ & $74.40 \pm 0.02 \mathrm{f}$ \\
\hline V2 & $12.10 \pm 0.01 \mathrm{~b}$ & $2.24 \pm 0.01 \mathrm{c}$ & $0.51 \pm 0.01 \mathrm{a}$ & $12.82 \pm 0.02 \mathrm{c}$ & $0.86 \pm 0.01 \mathrm{a}$ & $71.48 \pm 0.01 \mathrm{e}$ \\
\hline V3 & $12.10 \pm 0.01 \mathrm{~b}$ & $2.53 \pm 0.03 \mathrm{~d}$ & $0.51 \pm 0.01 \mathrm{a}$ & $15.17 \pm 0.03 \mathrm{~d}$ & $1.51 \pm 0.02 \mathrm{~d}$ & $68.18 \pm 0.06 \mathrm{~b}$ \\
\hline V4 & $12.25 \pm 0.01 \mathrm{c}$ & $1.74 \pm 0.04 \mathrm{~b}$ & $1.93 \pm 0.01 \mathrm{c}$ & $12.84 \pm 0.01 \mathrm{c}$ & $1.22 \pm 0.02 \mathrm{~b}$ & $70.02 \pm 0.04 \mathrm{~d}$ \\
\hline V5 & $13.96 \pm 0.00 \mathrm{e}$ & $4.25 \pm 0.02 \mathrm{f}$ & $0.99 \pm 0.03 \mathrm{~b}$ & $9.92 \pm 0.02 \mathrm{~b}$ & $1.47 \pm 0.01 \mathrm{c}$ & $69.41 \pm 0.03 \mathrm{c}$ \\
\hline V6 & $11.10 \pm 0.01 \mathrm{a}$ & $3.16 \pm 0.01 \mathrm{e}$ & $0.49 \pm 0.01 \mathrm{a}$ & $15.75 \pm 0.01 \mathrm{e}$ & $1.74 \pm 0.01 \mathrm{f}$ & $67.76 \pm 0.01 \mathrm{a}$ \\
\hline
\end{tabular}




\section{Discussion}

Determination of the proximate composition of different maize varieties is important so as to detect the varieties that are good sources of basic nutrients required for proper growth and development of either man or animals. Moisture content of food is of high economic importance to both the processor and consumer because the amount of moisture in food is inversely related to the amount of dry matter it contains. Moisture content is also significant to the stability and quality of food. Grains that contain high moisture are subject to rapid deterioration from mold growth, and insect damage to mention a few [8], [9]. The percentage moisture content of all the maize varieties studied ranged from $11.10 \pm 0.01$ to $13.96 \pm 0.00$; this is higher than the result recorded by Ape et al., [3] who recorded moisture content of $7.16 \%$ for maize bought from Ogbete market in Enugu, Nigeria. Crude fat is an important component of maize grains. Improvement in fat content aids good human health as they act as vehicle for fat soluble vitamins [10]. Percentage crude fat of the six analyzed maize varieties ranged from $1.29 \pm 0.01 \%-4.25 \pm 0.02 \%$. This is slightly similar to $4.07 \pm 0.02$ reported by Okonkwo and Agharandu [11] who analyzed maize purchased from Umuahia town market in Abia state, Nigeria. Foodstuffs are analyzed for $\%$ ash content so as to determine the non-organic matter component of the dry matter i.e. the remainder after oven drying, ignition or complete oxidation of organic matter present in the foodstuff. The ash content gives a rough idea of the total mineral amount present in the food. The ash content ranged from $0.49 \pm 0.01 \%$ - to $1.93 \pm 0.01 \%$, this is lower than $2.19 \%$ recorded by Ape et al., [3].

Proteins provide amino acids (for building and maintenance of the body) and energy occasionally. They are also used to produce nitrogen containing substances such as antibodies and enzymes which are important for normal body functions. Analyzed maize varieties had protein content between $9.92 \pm 0.02 \%$ and 15.75 $\pm 0.01 \%$; Okonkwo and Agharandu [11] reported a value of $10.79 \pm 0.01$ which falls within the range above. Crude fibre largely composed of cellulose and hemicellulose provides beneficial effects in humans by increasing water retention capacity during passage of food along the gut. A diet rich in crude fibre is considered healthy [12] because it helps in producing larger and softer faeces. The result of crude fibre of analyzed maize varieties ranged from $0.86 \% \pm 0.01$ to $1.74 \% \pm 0.01$; this is slightly lower than values reported by Ape et al., [3] and Okonkwo and Agharandu [11]. Maize is known to be rich in carbohydrate and as such, it provides energy, aid in utilization of body fats through metabolic process and help in the functioning of the intestinal tract. Percentage carbohydrate content of analyzed maize varieties were observed to fall between $67.76 \pm 0.01$ and $74.40 \pm 0.02$. This is in accordance with the results reported by Ape et al., [3] and Okonkwo and Agharandu [11]. The differences observed among the varieties could be due to genetic factors inherent in the different varieties, environmental factors or agronomic practices with which they were grown.

\section{Conclusion}

This research showed significant differences in the composition of the different maize varieties analyzed. Determination of the nutritional composition of different varieties of maize will help in providing information for effective guide on dietetics and selecting the best variety for consumption or other intended purposes. Of all the maize varieties studied, $\mathrm{V}_{6}$ (Big white) seems to be the most preferable for human and animal consumption because it has a significantly high protein content, a considerably high fat content and a significantly high crude fibre content.

\section{Acknowledgments}

The authors remain grateful to Mr. Adegboyega and the staff of Soil Science laboratory, Forestry Research Institute of Nigeria for the assistance rendered in the course of this study.

\section{How to Cite this Article:}

O. Adeniyi and O. Ariwoola, "Comparative Proximate Composition of Maize (Zea mays L.) Varieties Grown in Southwestern Nigeria", Int. Ann. Sci., vol. 7, no. 1, pp. 1-5, Jan. 2019. doi: $10.21467 /$ ias.7.1.1-5 


\section{References}

[1] R.S. Tajamul, P. Kamlesh and K. Pradyuman, "MaizeA potential source of human nutrition and health: A review", Cogent Food \& Agriculture, 2, 1, 2016.

[2] F. Hossain, V. Muthusamy, J.S. Bhat, S.K. Jha, R. Zunjare, A. Das, K. Sarika and R. Kumar, "Maize- Broadening the Genetic Base of Grain Cereals", Springer, pp 67-88, 2016.

[3] D.I. Ape, N.A. Nwogu, E.I. Uwakwe, C.S. Ikedinobi, "Comparative Proximate Analysis of Maize and Sorghum Bought from Ogbete Main Market of Enugu State, Nigeria", Greener Journal of Agricultural Sciences, 6, 9, pp. 272-275, 2016.

[4] H.K. Dei, “Assessment of Maize (Zea mays) as Feed Resource for poultry", Poultry $\quad$ Science, $\quad$ Milad Manafi, IntechOpen, 2017.

[5] S.Sheng, T. Li, R. Liu, "Corn phytochemicals and their health benefits" Food Science and Human Wellness, 7, 3, pp. 185-195, 2018.

[6] O.K. Ndukwe, H.O. Edeoga, G. Omosun, "Varietal Differences In Some Nutritional Composition of Ten Maize (Zea Mays L.) Varieties Grown In Nigeria", International Journal of Academic Research and Reflection, 3, 5, pp. 1-11, 2015.

[7] Association of Official Analytical Chemists (AOAC), "Official Methods of Analysis of AOAC International, 17th ed."; AOAC International: Gaithersburg, MD, USA, 2000.

[8] R. Suleiman, K. A. Rosentrater, C.Bern, "Effects of Deterioration Parameters on Storage of Maize: A Review", Journal of Natural Sciences Research, 3,9,pp. $147-165,2013$

[9] L. Sweets, "Stored Grain Fungi", Agricultural Electronic Bulletin Board -University of Missouri ExtensionCAFNR, 2018.

[10] E. Reboul, "Vitamin E Bioavailability: Mechanisms of Intestinal Absorption in the Spotlight",

Antioxidants, 6, 95, 2017.

[11] C. Okonkwo and U. Agharandu, "Proximate and Vitamin Composition of Selected Cereals commonly used for weaning Babies' Food Preparation in SouthEastern Nigeria, Journal of Biology, Agriculture and Healthcare, 7, 22, 2017.

[12] E. Capuano, "The behavior of dietary fiber in the gastrointestinal tract determines it physiological effect", Critical Reviews in Food Science and Nutrition, 57, 16, 2017.

\section{Publish your research article in AIJR journals- $\checkmark$ Online Submission and Tracking $\checkmark$ Peer-Reviewed \\ $\checkmark$ Rapid decision \\ $\checkmark \quad$ Immediate Publication after acceptance \\ $\checkmark$ Articles freely available online \\ $\checkmark \quad$ Retain full copyright of your article. \\ Submit your article at journals.aijr.in}

\section{Publish your books with AIJR publisher-}

$\checkmark$ Publish with ISBN and DOI.

$\checkmark$ Publish Thesis/Dissertation as Monograph.

$\checkmark$ Publish Book Monograph.

$\checkmark$ Publish Edited Volume/ Book.

$\checkmark$ Publish Conference Proceedings

$\checkmark$ Retain full copyright of your books.

Submit your manuscript at books.aijr.org 